5 Kitchen WH, Campbell NT, Drew JH, Murton LJ, Roy RND, Yu VYH. Provision of perinata services and survival of extremely low birthweight infants in Victoria. Med f Aust 1983;2:314-8.

6 World Health Organisation. Recommended definitions, terminology and format for statistical table related to the perinatal period and use of a new certificate for cause of perinatal deaths. Acta Obstet Gynecol Scand 1977;56:247-53.

7 Spinnato, Sibai BM, Shaver DC, Anderson GD. Inaccuracy of Dubowitz gestational age in low birth weight infants. Obstet Gynecol 1984;63:491-5.

8 Kitchen WH, Yu VYH, Orgill AA, et al. Collaborative study of very low birthweight infants: outcome of two year old survivors. Lancet 1982;i:1457-61.

9 Orgill AA, Astbury J, Bajuk B, Yu VYH. Early development of infants $1000 \mathrm{~g}$ or less at birth. Arch Dis Child 1982;57:823-7.

10 Yu VYH, Wong PY, Bajuk B, Orgill AA, Astbury J. Outcome of extremely low birthweight infants. Br J Obstet Gynaecol 1986;93:162-70.

11 Stewart AL, Turcan DM, Rawlings G, Reynolds EOR. Prognosis for infants weighing $1000 \mathrm{~g}$ or less at birth. Arch Dis Child 1977;52:97-104.

12 Kitchen WH, Bajuk B, Lissenden JV, Yu VYH. Intrauterine growth charts from 24 to 29 weeks' gestation. Aust Paediatr 7 1981;17:269-72.

13 Britton SB, Fritzhardinge PM, Ashby S. Is intensive care justified for infants weighing less than $801 \mathrm{~g}$ at birth? I Pediatr 1981;99:937-43.

14 Bennett FC, Robinson NM, Sells CJ. Growth and development of infants weighing less than 800 grams at birth. Pediatrics 1983;71:319-23.

15 Hirata T, Epcar JT, Walsh A, et al. Survival and outcome of infants 501 to $750 \mathrm{gm}$ : a six yea experience. $\mathcal{F}$ Pediatr 1983;102:741-8.

16 Buckwald S, Zorn WA, Egan EA. Mortality and follow-up data for neonates weighing $500-800 \mathrm{~g}$ at birth. Am F Dis Child 1984;138:779-82.

17 Hack M, Fanaroff AA. Changes in the delivery room care of the extremely small infant $(<750 \mathrm{~g})$. Effects on morbidity and outcome. $N$ Engl $7 \mathrm{Med} 1986 ; 314: 660$-t.

18 Kitchen W, Ford G, Orgill AA, et al. Outcome of infants of birthweight $500-599 \mathrm{~g}$ : a regional study of 1979-1980 births. $\mathcal{F}$ Pediatr 1984;104:921-7.

19 Dillon WP, Egan EA. Aggressive obstetric management in late second-trimester deliveries. Obstet Gynecol 1981;58:685-90.

20 Herschel M, Kennedy JL, Jr, Kayne HL, Henry M, Cetrulo CL. Survival of infants born at 24 to 28 weeks' gestation. Obstet Gynecol 1982;60:154-8.

21 Yu VYH, Watkins A, Bajuk B. Neonatal and postneonatal mortality in very low birthweight infants. Arch Dis Child 1984;59:987-99.

22 Bhat R, Raju TNK, Vidyasagar D. Immediate and long-term outcome of infants less than 1000 grams. Crit Care Med 1978;6:147-50

23 Pape KE, Buncic RJ, Ashby S, Fitzhardinge PM. The status at two years of low birthweigh infants born in 1974 with birthweights of less than $1001 \mathrm{~g}$. F Pediatr 1978;92:253-60.

24 Shennan AT, Milligan JE, Hoskins EM. Perinatal factors associated with death or handicap in very preterm infants. Am $\mathcal{F}$ Obstet Gynecol 1985;151:231-8.
25 Khoury MJ, Marks JS, McCarthy BJ, Zaro SM. Factors affecting the sex differential in neonatal mortality: the role of respiratory distress syndrome. Am f Obstet Gynecol 1985;151:777-82. 26 McCarthy BJ, Sachs BP, Layde PM, Burton A, Terry JS, Rochat R. The epidemiology of neonatal deaths in twins. Am $\mathcal{F}$ Obstet Gynecol 1981;141:252-6.

27 Hawrylyshyn PA, Barkin M, Bernstein A, Papsin FR. Twin pregnancies-a continuing perinatal challenge. Obstet Gynecol 1982;59:463-6.

28 Barrett JM, Staggs SM, Van Hooydonk JE, Growdon JH, Killam AP, Boem FH. The effect of delivery upon neonatal outcome in premature twins. Am 7 Obstet Gynecol 1982;143:360-4.

29 Chervenak FA, Johnson RE, Berkowitz RL, Grannum P, Hobbins JC. Is routine cesarean section necessary for vertex-breech and vertex-transverse twin gestations? Am $\mathcal{f}$ Obstet Gynecol 1984;148: 1-5.

30 Bell D, Johnansson D, McLean FH, Usher RH. Birth asphyxia, trauma, and mortality in twins: has cesarean section improved outcome? Am $\mathcal{F}$ Obstet Gynecol 1986;154:235-9.

31 Yu VYH, Downe L, Astbury J, Orgill AA, Bajuk B. Perinatal factors associated with adverse outcome in extremely low birthweight infants. Arch Dis Child 1986;61:554-8.

32 Szymonowicz W, Yu VYH, Bajuk B, Astbury J. Neurodevelopmental outcome of periventricular haemorrhage and leukomalacia in infants 1250 grams or less at birth. Early Hum Dev 1986;14: haem.

33 Szymonowicz W, Yu VYH. Periventricular haemorrhage and leukomalacia in extremely low birthweight infants. Aust Paediatr F 1986;22:207-10

34 Yu VYH, Orgill AA, Lim SB, Bajuk B. Astbury J. Growth and development of very low birthweight children recovering from bronchopulmonary dysplasia. Arch Dis Child 1983;58 791-4.

35 Morgan MEI. Late morbidity of very low birthweight infants. Br Med f 1985;291:171-3.

36 Astbury J, Orgill AA, Bajuk B, Yu VYH. Neonatal and neurodevelopmental significance of behaviour in very low birthweight children. Early Hum Dev 1985;11:113-21.

37 Astbury J, Orgill AA, Bajuk B, Yu VYH. The physical and neurobehavioural sequelae of growth failure in appropriate for gestational age very low birthweight children. Dev Med Child Neurol (in press).

38 Enhorning G, Shennan A, Possmayer F, Dunn M, Chen CP, Milligan J. Prevention of neonatal repiratory distress syndrome by tracheal instillation of surfactant: a randomised clinical trial. Pediatrics 1986;76:145-53.

39 Boynton BR, Mannino FL, Davis RF, Kopotic RJ, Friederichsen G. Combined high-frequency oscillatory ventilation in critically ill neonates. F Pediatr 1984;105:297-302.

40 Yu VYH, Bajuk B, Orgill AA, Astbury J. Viability of infants born at 24 to 26 weeks' gestation. Ann Acad Med 1985;14:563-71.

41 Yu VYH, Davis NG, Mercado M, Bajuk B, Astbury J. Subsequent pregnancy following the birth of an extremely low birthweight infant. Aust NZ F Obstet Gynaecol 1986;26:115-9.

(Accepted 14 August 1986)

\title{
Hip fractures in healthy patients: operative delay versus prognosis
}

\author{
R N VILLAR, S M ALLEN, S J BARNES
}

\begin{abstract}
One hundred and forty five women who had undergone hemiarthroplasty for a subcapital fracture of the femoral neck but who were otherwise fit were studied to determine whether undue delay between injury and operation influenced their social circumstances three months after surgery. The median delay for those patients who showed good rehabilitation at three months was 29 hours, but for those who showed poor rehabilitation it was 57 hours. This difference was significant.

It is suggested that a subcapital fracture in an otherwise fit elderly patient should therefore be regarded as a surgical emergency.
\end{abstract}

\section{Introduction}

It is widely accepted that elderly women with hip fractures undergo surgery on the next available operating list, frequently 24 hours or

\footnotetext{
Department of Orthopaedic Surgery, Southampton General Hospital, Southampton, Hants

R N VILLAR, BSC, FRCS, orthopaedic registrar

S M ALLEN, MB, BS, orthopaedic senior house officer

S J BARNES, BM, orthopaedic senior house officer

Correspondence to: $\mathrm{Mr} \mathbf{R} \mathrm{N}$ Villar, Department of Orthopaedic Surgery, Addenbrooke's Hospital, Cambridge CB2 2QQ.
}

more after admission. We present a retrospective study relating this operative delay to the social circumstances of the patient three months after surgery.

\section{Patients, methods, and results}

We studied 205 consecutive women patients, who had been admitted over 18 months and had undergone hemiarthroplasty for a displaced subcapital fracture of the femoral neck. Of the 205 patients, 60 had intercurrent illness that was likely to interfere with postoperative rehabilitation and were excluded from the study.

The social circumstances of each patient were assessed on admission and three months after surgery as $(a)$ independent if she lived without help from others; $(b)$ sheltered if she received substantial help with daily activities; or (c) resident in hospital if she lived in an institution. ${ }^{1}$ The time delay between injury and operation and typical reasons for delay were also recorded. At the review three months after surgery each patient was placed in one of two groups based on her social circumstances at that time. Group A consisted of patients whose circumstances were similar to those on admission, and group $\mathrm{B}$ consisted of patients whose circumstances had deteriorated and those who had died.

Statistical analysis was by Student's $t$ test. Results for operative delay produced a skewed distribution and $\log _{e}$ (operative delay) was therefore used to correct the findings.

Of the 145 patients, $98(68 \%)$ were admitted from an independent environment, $41(28 \%)$ were sheltered, and $6(4 \%)$ were resident in hospital. After three months similar percentages of each social category could be placed in group A $(81 \%$ independent, $78 \%$ sheltered, and $83 \%$ resident in hospital). No patient improved after surgery; a patient stayed the same, became worse, or died.

Patients in group A had a median delay of 29 (range 6-184 h; mean $31 \cdot 7 \mathrm{~h}$ ) and group B patients a median delay of 57 (range $24-528 \mathrm{~h}$; mean $74 \cdot 7 \mathrm{~h}$ ). 
The difference between the mean operative delays in the two groups was therefore 43 hours $(95 \%$ confidence interval $41 \cdot 35$ to $44 \cdot 45 \mathrm{~h} ; t=6 \cdot 0,143 \mathrm{df}$; $\mathrm{p}<0.0001)$. Despite a slight difference in the median ages for groups A and B ( 80 (range 47-96) and 82 (range 69-93), respectively) age distributions were similar. Typical reasons for delay included operator fatigue, delay in diagnosis, lack of theatre time, industrial action, and lack of patient's consent.

\section{Discussion}

This retrospective study suggests that the longer an otherwise fit patient has to wait for her hip fracture to be treated the less she will progress after discharge, regardless of her social circumstances. Many hospitals use trauma list systems, patients admitted one day being held over to the next before undergoing surgery. Previous work has shown that delays of 13-48 hours are not necessarily detrimental to patients' wellbeing. ${ }^{2}$ Such work, however, emphasises the delay between admission and surgery rather than between injury and operation, the two observations often being widely different. Some of our patients had languished at home for several days before being admitted to hospital; thus in these cases there was a short interval between admission and surgery but an $\underline{0}$ unacceptable delay between injury and surgery.

Loss of independence is perhaps the most important social problem relating to patients with fractures of the femoral neck, $c$ resulting in blocked beds and overloading of social and primary care $\widehat{C}$ services. What then should be done to avoid this for the elderly $\bar{\equiv}$ patient who arrives in the accident and emergency department with $x$ a hip fracture? We believe that if she is otherwise fit every effort $\mathbb{D}$ should be made for her to undergo surgery at the earliest m opportunity. To include such patients in a standard trauma list system, however convenient it may be for surgeons, anaesthetists, $\vec{\Rightarrow}$ and administrators, is to exacerbate a situation that is already out of $\stackrel{\mathcal{S}}{+}$ control.

\section{References} intertrochanteric $\overrightarrow{0}$ fractures. I Bone foint Surg [Br] 1981;63:24-8.

2 Aldrete JA, Davis HS, Hingson RA. Anesthesia factors in the surgical management of hip $\rightarrow$ fractures. $\mathcal{F}$ Trauma 1967;7:818-26.

Accepred 20 Auqust 1986)

\title{
Trial of early nifedipine in acute myocardial infarction: the Trent study
}

\author{
R G WILCOX, J R HAMPTON, D C BANKS, J S BIRKHEAD, I A B BROOKSBY, \\ C J BURNS-COX, M J HAYES, M D JOY, A D MALCOLM, H G MATHER, J M ROWLEY
}

\begin{abstract}
Over 30 months 9292 consecutive patients admitted to nine coronary care units with suspected myocardial infarction were considered for admission to a randomised double blind study comparing the effect on mortality of nifedipine $10 \mathrm{mg}$ four times a day with that of placebo. Among the $\mathbf{4 8 0 1}$ patients excluded from the study the overall one month fatality rate was $18 \cdot 2 \%$ and the one month fatality rate in those with definite myocardial infarction $\mathbf{2 6 . 8 \%}$. A total of $\mathbf{4 4 9 1}$ patients fulfilled the entry criteria and were randomly allocated to nifedipine or placebo immediately after assessment in the coronary care unit. Roughly $64 \%$ of patients in both treatment groups sustained an acute myocardial infarction. The overall one month fatality rates were $6.3 \%$ in the placebo treated group and $\mathbf{6 . 7 \%}$ in the nifedipine treated group. Most of the deaths occurred in patients with an in hospital
\end{abstract}

\section{TRENT Study Group}

Coordinator: Dr R G Wilcox. Chairman: Professor I R Hampton (University Hospital, Nottingham). Principal investigators: Dr D C Banks (City Hospital, Nottingham); Dr J S Birkhead (General Hospital, Northampton); Dr I A B Brooksby (Norfolk and Norwich Hospital, Norwich); Dr C J Burns-Cox (Frenchay Hospital, Bristol); Dr M J Hayes (Princess Margaret Hospital, Swindon); Dr M D Joy (St Peter's Hospital, Chertsey); Dr A D Malcolm (Airedale General Hospital, Keighley); Dr H G Mather (Southmead Hospital, Bristol); Dr J M Rowley (University Hospital, Nottingham); Dr R G Wilcox (University Hospital, Nottingham). Data analysis: Dr A M Skene, Pamela Skene, Professor A F M Smith (department of mathematics, University of Nottingham). Ethical review committee: Professor G A Rose, Professor M J Healy, Professor P Sever (London School of Hygiene and Tropical Medicine, St Mary's Hospital, London). Bayer clinical research coordinators: Dr G Macdonald, Dr K Young.

Correspondence to: Dr R G Wilcox, Department of Medicine, University Hospital, Queen's Medical Centre, Nottingham. diagnosis of myocardial infarction, and their one month fatality rates were $9.3 \%$ for the placebo group and $10.2 \%$ for the nifedipine group. These differences were not statistically significant. Subgroup analysis also did not suggest any particular $\frac{}{\varnothing}$ group of patients with suspected acute myocardial infarction who might benefit from early nifedipine treatment in the dose studied.

\section{Introduction}

Nifedipine is a substituted dihydropyridine with calcium channel blocking properties. ${ }^{\prime}$ Compared with verapamil it has very little $\dot{0}$ cardiac electrophysiological effect. ${ }^{2}$ In experimental myocardial 3. infarction in animals pretreatment with nifedipine in a dose 8 carefully regulated to avoid a large fall in blood pressure and reflex tachycardia causes an increase in coronary blood flow in both 윽 normally perfused and ischaemic areas of the heart, delays the $N$ release of cytoplasmic enzymes and the intracellular accumulation of calcium, preserves intracellular stores of adenosine triphosphate, and reduces infarct size. ${ }^{3.6}$ Nifedipine is active during periods of ischaemia and also during subsequent reperfusion. ${ }^{3}$ This has led to $\tilde{O}$ speculation that the drug may have a "cardioprotective" action in $\omega$ man.

In angina nifedipine has been shown to increase coronary 0 perfusion and decrease afterload with minimal decrease in con- $\bar{\Phi}$ tractility ${ }^{7}$ and is thereby thought to stabilise the imbalance between $\stackrel{+}{+}$ oxygen supply and oxygen demand. Roberts and coworkers have $\frac{T}{0}$ shown that nifedipine produces similar haemodynamic effects in patients with acute infarction, suggesting that in this condition also the drug may be capable of improving a myocardial oxygen $\stackrel{\varnothing}{\AA}$ deficiency. ${ }^{9}$ Nifedipine also inhibits coronary artery spasm ${ }^{10}{ }^{11}$ and $\overline{2}$ exerts a mild antiaggregatory effect on platelets, ${ }^{12}$ both effects that 8 have been implicated in myocardial infarction. ${ }^{13}$

The study by Roberts et al also suggested that treatment with 